\title{
Design, obtainment and properties of glasses and glass-ceramics from coal fly ash
}

Luisa Barbieri $^{\mathrm{a}}$, Isabella Lancellotti ${ }^{\mathrm{a}}$, Tiziano Manfredini ${ }^{\mathrm{a}}$, Ignasi Queralt ${ }^{\mathrm{b}}$, Jesús Ma Rincón ${ }^{\mathrm{c}}$, Maximina Romero ${ }^{\mathrm{c}}$

${ }^{a}$ Department of Chemistry, Faculty of Engineering, University of Modena, Via Campi 183, 41100 Modena, Italy

b Institute of Earth Sciences "Jaume Almera", CSIC, Solè Sabarís s/n, 08028 Barcelona, Spain

c The Glass-Ceramics Lab, Institute of Construction Sciences "Eduardo Torroja", CSIC, C/Serrano Galvache s/n, 28033 Madrid, Spain

\begin{abstract}
Glasses and glass-ceramics were obtained by mixing up to $50 \mathrm{wt} \%$ of Italian or Spanish coal fly ash with other wastes (glass cullet and float dolomite). The behaviour of 10 compositions was investigated by thermal (DTA) and mineralogical (XRD) analysis, microstructural (SEM) characterization, mechanical and chemical measurements. It was verified that the contribution of the alkaline-earth elements in the original composition is fundamental to easily obtain glassceramics with a fine microstructure which improves the mechanical properties. Otherwise, with a small addition of fly ash and without dolomite, very stable glassy materials were obtained that did not exhibit any visible etching either in water or in acid media. Therefore, the combined vitrification/devitrification technique is a suitable methodology for the recycling and exploitation of coal fly ash.
\end{abstract}

Keywords: Fly ash; Glass; Glass-ceramics

\section{Introduction}

A large amount of fly ash is produced in the world as a by-product of coal combustion in power stations. Currently, only a small percentage of this waste is utilized, mainly in the cement industry [1], the remainder being directly discharged into fly ash ponds or landfills. This gives rise to social and economic problems resulting in cost increase (transport, inertization treatments, disposal). Moreover, national regulations are reinforcing environmental protection 
measures, thus rendering the development of new recycling technologies necessary and convenient. Indeed, attempts to utilize fly ash are not new; several more efficient uses have been proposed in the last 40 years, including brick and ceramic tile manufacture, lightweight aggregate, road pavements, fillers in plastics and paints, mineral wool and for metal recovery. Most recently the development of new ceramic and glass-ceramic materials, made by recycling coal fly ash, has been acquiring particular importance [2], [3], [4], [5], [6] and [7]. The main reasons lie in some characteristics of the waste itself and in the properties of the combined vitrification/devitrification technique. The chemical composition of fly ash is typical of the most common glassy ternary system $\left(\mathrm{CaO}-\mathrm{Al}_{2} \mathrm{O}_{3}-\mathrm{SiO}_{2}\right)$ with significant amounts of transition metal oxides which are able to act as nucleant agents for nucleation and crystallization; furthermore, the presence of glassy microspheres increases the reactivity of this waste; the fine powder form makes it ready for mixing with other ingredients in a batch. Moreover, glass and glass-ceramic technology is able to convert at a low cost complex chemical compositions into useful materials with substantial perspectives of market exploitation, absorbing at the same time dangerous elements that may be present in the batch into a homogeneous chemically inert glassy matrix.

In this paper we tested the vitrification/devitrification capability of Italian and Spanish coal fly ash as a function of their significantly different chemical composition and of the additions of other inorganic wastes, appropriately introduced to make the formation of amorphous and semicrystallized materials easy.

\section{Materials and methods}

Different waste raw materials were used to make the glass synthesis process as cheap as possible (Table 1). Binary compositions were prepared by mixing glass cullet of conventional glass production with $10-50 \mathrm{wt} \%$ of coal fly ash, either Spanish (Teruel and Meirama-from the northeast and the northwest, respectively) or Italian (Rete 2-Reggio Emilia, in the north), very different in $\mathrm{SiO}_{2}, \mathrm{Al}_{2} \mathrm{O}_{3}$ and $\mathrm{CaO}$ content. The glass cullet ensures the presence of a significant amount of silica glass former and melting oxides such as $\mathrm{Na}_{2} \mathrm{O}$ and $\mathrm{CaO}$. To improve the stability and the moulding of the glass and its tendency towards the crystallization, a $30 \mathrm{wt} \%$ of float dolomite (from Spanish mineral extraction operations) as $\mathrm{CaO}$ and $\mathrm{MgO}$ bearer was also used to realize three ternary formulations (4T, $4 \mathrm{M}$ and $4 \mathrm{RC}$ ). Ten different batches (Table 2) were obtained by ball milling the as-received fly ash, calcined for $1 \mathrm{~h}$ at $1100^{\circ} \mathrm{C}$ (to avoid possible problems of degassing reactions during melting), and dolomite with grounded glass cullet, packing them in refractory crucibles and placing in a high temperature electric furnace. 
The small disagreement, evident in the table, between the calculated and the experimental data, typical in particular of the dolomite-containing compositions, is probably due to a reaction of the melting batch with the crucible (prevalently made of mullite, $3 \mathrm{Al}_{2} \mathrm{O}_{3} \cdot 2 \mathrm{SiO}_{2}$ ). The melting temperature was about $1500^{\circ} \mathrm{C}$ (thermal cycles of $5 \mathrm{~h}$ ), after which the glass was poured in a steel mould, annealed at $550^{\circ} \mathrm{C}$ for $2 \mathrm{~h}$, then cut by a diamond saw blade in equal pieces $(1 \times 1 \times 0.5 \mathrm{~cm})$ for subjection to different devitrification thermal treatments.

Table 1. Chemical analysis (wt $\%)$ of the waste raw materials

\begin{tabular}{crrrr}
\hline $\begin{array}{c}\text { Meirama } \\
\text { Spanish fly ash }\end{array}$ & $\begin{array}{c}\text { Teruel Spanish } \\
\text { fly ash }\end{array}$ & $\begin{array}{c}\text { Rete 2 Italian } \\
\text { fly ash }\end{array}$ & Glass cullet & Float dolomite \\
& & & & \\
58.88 & 51.56 & 15.17 & 70.49 & 1.01 \\
25.5 & 29.13 & 7.14 & 2.12 & 0.26 \\
5.64 & 4.21 & 23.71 & 11.81 & 30.2 \\
1.12 & 1.62 & 1.35 & 2.68 & 19.53 \\
0.28 & 0.26 & 0.9 & 11.9 & 0.04 \\
0.49 & 0.82 & 0.44 & 0.83 & 0 \\
6.58 & 4.78 & 3.76 & 0.29 & 3.48 \\
1.24 & 1.66 & 0.31 & 0.07 & 0.02 \\
\hline
\end{tabular}

The theoretical tendency towards crystallization was evaluated by the method of Ginsberg applied to the natural rocks [8]. Thermal parameters, i.e. glass transition, crystallization and melting temperatures, were determined by high precision differential thermal analysis (Netzsch DSC 404), heating the glassy powders (particles less than $20 \mu \mathrm{m}$ in size) from $20^{\circ}$ to $1400^{\circ} \mathrm{C}$ at the rate of $10^{\circ} \mathrm{C} / \mathrm{min}$ in static air. Mineralogical analysis was performed by powder X-ray diffraction (Philips PW 3710) on powders of about $20 \mu \mathrm{m}$ and in the $2 \theta 5^{\circ}-60^{\circ}$ range. From the XRD data, the TTT curves of nucleation and crystallization were obtained. Microstructure characterization was performed on the semicrystalline materials by scanning electron microscopy (SEM) (Philips XL 40) and energy dispersion X-ray fluorescence spectroscopy (EDS) over sputter coated samples with $\mathrm{Au} / \mathrm{Pd}$ for simultaneous microanalysis. The SEM samples were cut and embedded in epoxy resin and subsequently polished with $\mathrm{SiC}$ and $\mathrm{Al}_{2} \mathrm{O}_{3}$ paste $(0.5-0.3 \mu \mathrm{m})$. Vickers $\left(H_{\mathrm{V}}\right)$ and Knoop $\left(H_{\mathrm{K}}\right)$ microhardness, elasticity modulus $(E)$ and toughness $\left(K_{\mathrm{IC}}\right)$ were measured by a Digital Micro Hardness Tester (Matsuzawa DMH 2) over polished specimens of glasses and glass-ceramics embedded in the epoxy resin. Calculations of $E$ and $K_{\mathrm{IC}}$ followed published procedures [9] and [10]. The chemical resistance was determined through the Materials Characterization Center MCC-1 Test Method [11] and [12] on monolithic 
prismatic specimens after the same polishing above mentioned both in water and in $\mathrm{HNO}_{3}$ $0.1 \mathrm{M}$ at room temperature for two different times (1 and 2 weeks, respectively).

Table 2. Formulated and ICP average composition (wt $\%$ ) of original glasses containing Spanish and Italian fly ash

\begin{tabular}{|c|c|c|c|c|c|c|}
\hline Spanish fly ash & $1 \mathrm{~T}$ & $2 \mathrm{~T}$ & $4 \mathrm{~T}$ & $4 \mathrm{M}$ & & \\
\hline \multicolumn{7}{|l|}{ Oxide } \\
\hline $\mathrm{SiO}_{2}$ & $68.89 / 68.65$ & $67.41 / 67.62$ & $50.07 / 51.71$ & $52.13 / 52.43$ & & \\
\hline $\mathrm{Al}_{2} \mathrm{O}_{3}$ & $4.84 / 4.82$ & $7.60 / 7.37$ & $14.71 / 16.77$ & $12.64 / 15.61$ & & \\
\hline $\mathrm{CaO}$ & $11.10 / 10.04$ & $10.40 / 9.19$ & $17.00 / 14.85$ & $17.22 / 15.89$ & & \\
\hline $\mathrm{MgO}$ & $2.59 / 2.33$ & $2.49 / 2.31$ & $8.70 / 7.27$ & $8.24 / 7.30$ & & \\
\hline $\mathrm{Na}_{2} \mathrm{O}$ & $10.78 / 9.82$ & $9.67 / 8.67$ & $4.39 / 3.27$ & $4.28 / 3.42$ & & \\
\hline $\mathrm{K}_{2} \mathrm{O}$ & $0.83 / 0.70$ & $0.84 / 0.56$ & $0.69 / 0.56$ & $0.52 / 0.61$ & & \\
\hline $\mathrm{Fe}_{2} \mathrm{O}_{3}{ }^{\mathrm{a}}$ & $0.74 / 0.82$ & $1.20 / 1.37$ & $3.62 / 3.49$ & $4.36 / 3.36$ & & \\
\hline $\mathrm{TiO}_{2}$ & $0.23 / 0.24$ & $0.39 / 0.41$ & $0.82 / 0.87$ & $0.61 / 0.79$ & & \\
\hline Italian fly ash & $1 \mathrm{RE}$ & $2 \mathrm{RE}$ & $3 R E$ & $4 \mathrm{RE}$ & $5 \mathrm{RE}$ & $4 \mathrm{RC}$ \\
\hline \multicolumn{7}{|l|}{ Oxide } \\
\hline $\mathrm{SiO}_{2}$ & $68.05 / 66.62$ & $65.52 / 65.75$ & $62.69 / 62.06$ & $59.54 / 58.80$ & $56.00 / 54.68$ & $40.74 / 44.44$ \\
\hline $\mathrm{Al}_{2} \mathrm{O}_{3}$ & $2.75 / 3.37$ & $3.44 / 4.63$ & $4.22 / 5.50$ & $5.08 / 6.99$ & $6.05 / 9.16$ & $5.29 / 9.47$ \\
\hline $\mathrm{CaO}$ & $13.62 / 13.08$ & $15.64 / 15.88$ & $17.89 / 19.56$ & $20.40 / 22.35$ & $23.22 / 25.18$ & $32.71 / 30.88$ \\
\hline $\mathrm{MgO}$ & $2.67 / 2.36$ & $2.66 / 2.51$ & $2.65 / 2.50$ & $2.65 / 2.42$ & $2.63 / 2.25$ & $10.67 / 8.15$ \\
\hline $\mathrm{Na}_{2} \mathrm{O}$ & $11.31 / 9.18$ & $10.69 / 8.65$ & $10.00 / 7.27$ & $9.23 / 6.39$ & $8.37 / 5.59$ & $5.84 / 3.66$ \\
\hline $\mathrm{K}_{2} \mathrm{O}$ & $0.83 / 0.52$ & $0.83 / 0.45$ & $0.83 / 0.25$ & $0.83 / 0.45$ & $0.83 / 0.45$ & $0.63 / 0.28$ \\
\hline $\mathrm{Fe}_{2} \mathrm{O}_{3}{ }^{\mathrm{a}}$ & $0.67 / 0.90$ & $1.09 / 1.57$ & $1.55 / 2.03$ & $2.07 / 2.60$ & $2.65 / 3.31$ & $3.90 / 2.31$ \\
\hline $\mathrm{TiO}_{2}$ & $0.10 / 0.12$ & $0.13 / 0.18$ & $0.17 / 0.22$ & $0.20 / 0.29$ & $0.25 / 0.36$ & $0.22 / 0.35$ \\
\hline
\end{tabular}

\section{Results and discussion}

The mixing and melting of the waste raw materials from Table 1 give differently coloured glasses (dark/brown to transparent green).

The capability of the different original glasses here investigated to produce suitable glassceramics is shown in the Ginsberg $\left(\mathrm{Sal}=\mathrm{SiO}_{2}+\mathrm{Al}_{2} \mathrm{O}_{3} ; \mathrm{Cafem}=\mathrm{CaO}+\left(\mathrm{FeO}\right.\right.$ and $\left.\mathrm{Fe}_{2} \mathrm{O}_{3}\right)+\mathrm{MgO}$; $\mathrm{Alk}=\mathrm{Na}_{2} \mathrm{O}+\mathrm{K}_{2} \mathrm{O}$ ) diagram reported in Fig. 1. Theoretically, the ternary compositions containing Spanish fly ash and those with a higher percentage of Italian fly ash are the most adequate for giving good devitrified products, being located in the $60-70 \%$ Sal band. Only the 4RC glass formulation under this zone contains too high an amount of modifiers that destabilize the glass 
network; however, the binary formulations with 10 or $20 \%$ of fly ash have a higher $\mathrm{SiO}_{2}$ content that, by conferring to the network a very rigid structure, makes the processing operations difficult.

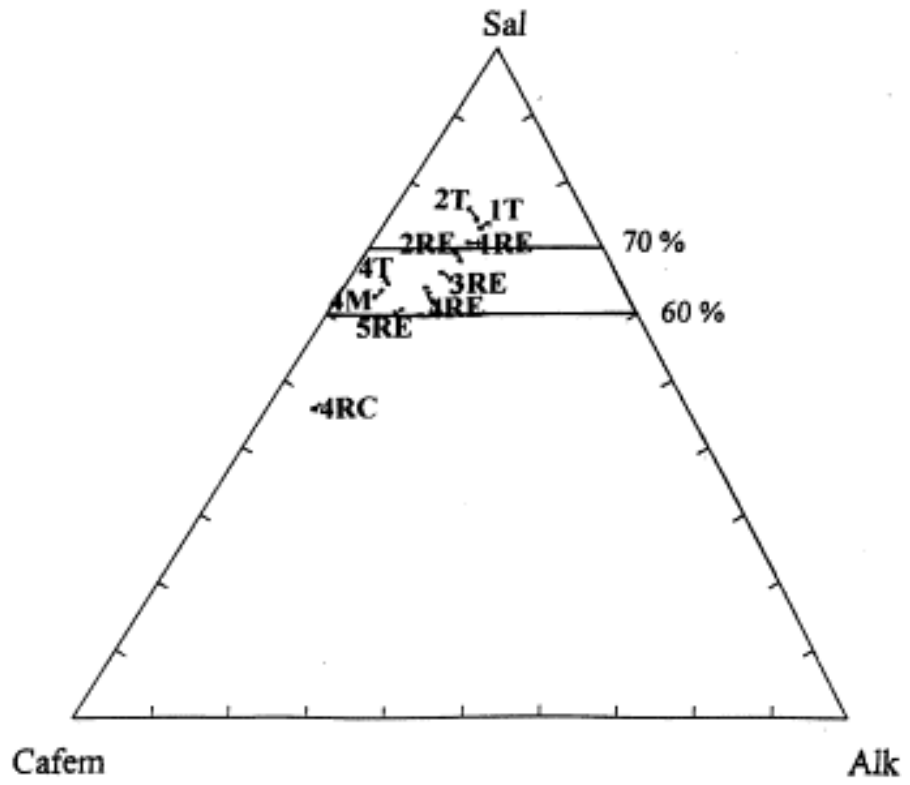

Fig. 1. Ginsberg diagram of the glassy compositions here investigated $\left(\mathrm{Sal}=\mathrm{SiO}_{2}+\mathrm{Al}_{2} \mathrm{O}_{3}\right.$; $\mathrm{Cafem}=\mathrm{CaO}+\left(\mathrm{FeO}\right.$ and $\left.\left.\mathrm{Fe}_{2} \mathrm{O}_{3}\right)+\mathrm{MgO} ; \mathrm{Alk}=\mathrm{Na}_{2} \mathrm{O}+\mathrm{K}_{2} \mathrm{O}\right)$.

DTA experiments showed the existence of two glassy families (Fig. 2): the first very stable with no clear exothermic effects in the temperature nucleation and crystallization range (1T and $2 \mathrm{~T}$ glasses) and the second with a sharp exothermic peak of crystallization near $900^{\circ} \mathrm{C}$ (4T and $4 \mathrm{M}$ glasses). Glass transition, crystallization and melting temperatures generally increase by increasing the $\mathrm{CaO}$ and $\mathrm{MgO}$ contents with respect to the alkaline oxides and the iron oxides. The ternary compositions ( $4 \mathrm{~T}, 4 \mathrm{M}$ and $4 \mathrm{RC}$ ) that have the highest amounts of the above mentioned oxides are the most capable of crystallization.

The role played by the alkaline-earth oxides and the nucleant iron oxides as fly ash content increase and dolomite addition on the devitrification process was well pointed out with the combined use of XRD and SEM analysis. The ternary formulations are those that present a major tendency towards devitrification precipitating dendritic pyroxene (e.g. diopside), Fe-rich spinels and feldspars of calcium and/or sodium. However, acicular wollastonite is almost always the only phase present in the binary compositions, which show less volume fraction of crystallization after longer heat treatments for 8-16 h. Instead, as far as $4 \mathrm{RC}$ formulation is concerned, the prevalent crystalline phase is akermanite and the kinetic of devitrification is very rapid (in only $30 \mathrm{~min}$ at $800^{\circ} \mathrm{C}$ the system goes from the amorphous to the total crystallized 
state). The SEM analysis in addition to comfirm the crystalline phases recognized by XRD pointed out a surface crystallization mechanism. This is evident in the micrograph of the $4 \mathrm{M}$ glass-ceramic obtained after $2 \mathrm{~h}$ at $1200^{\circ} \mathrm{C}$ (Fig. 3), which shows the crystalline network formed starting from the edge of the sample embedded in the glassy matrix.

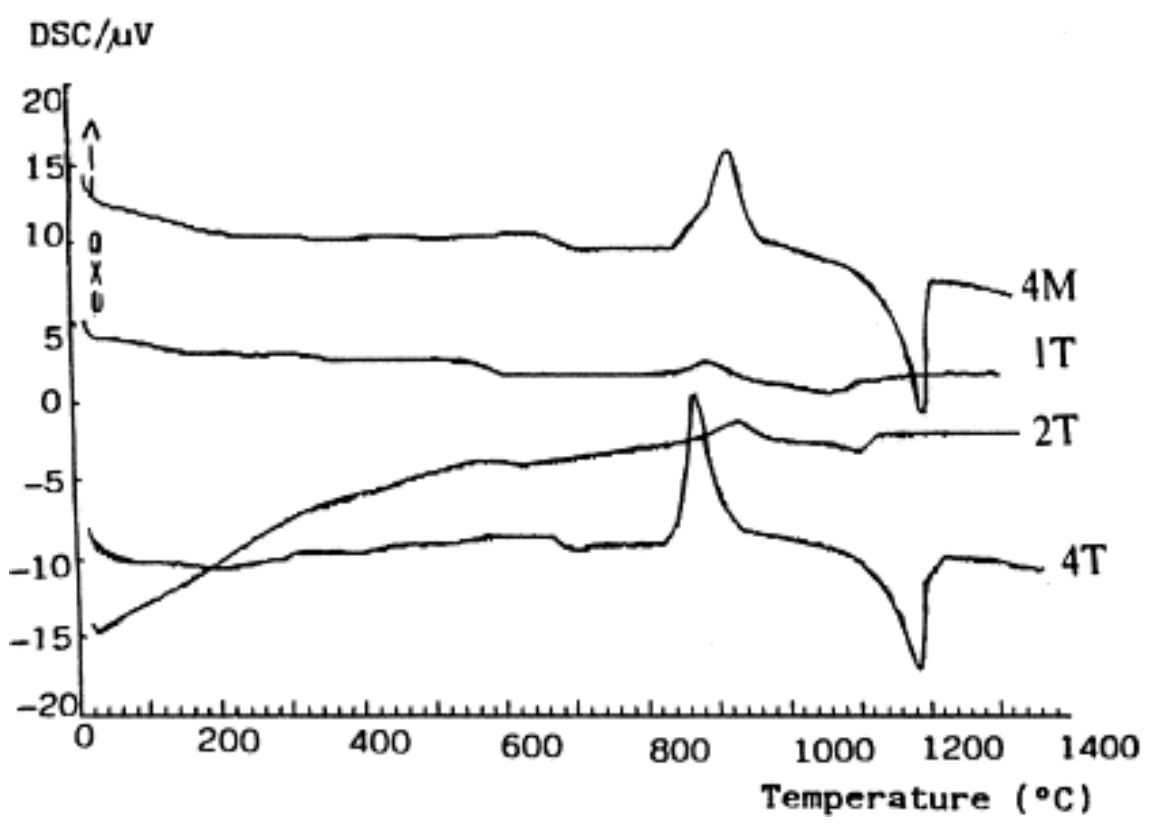

Fig. 2. DTA curve traces on glassy powders of different composition.

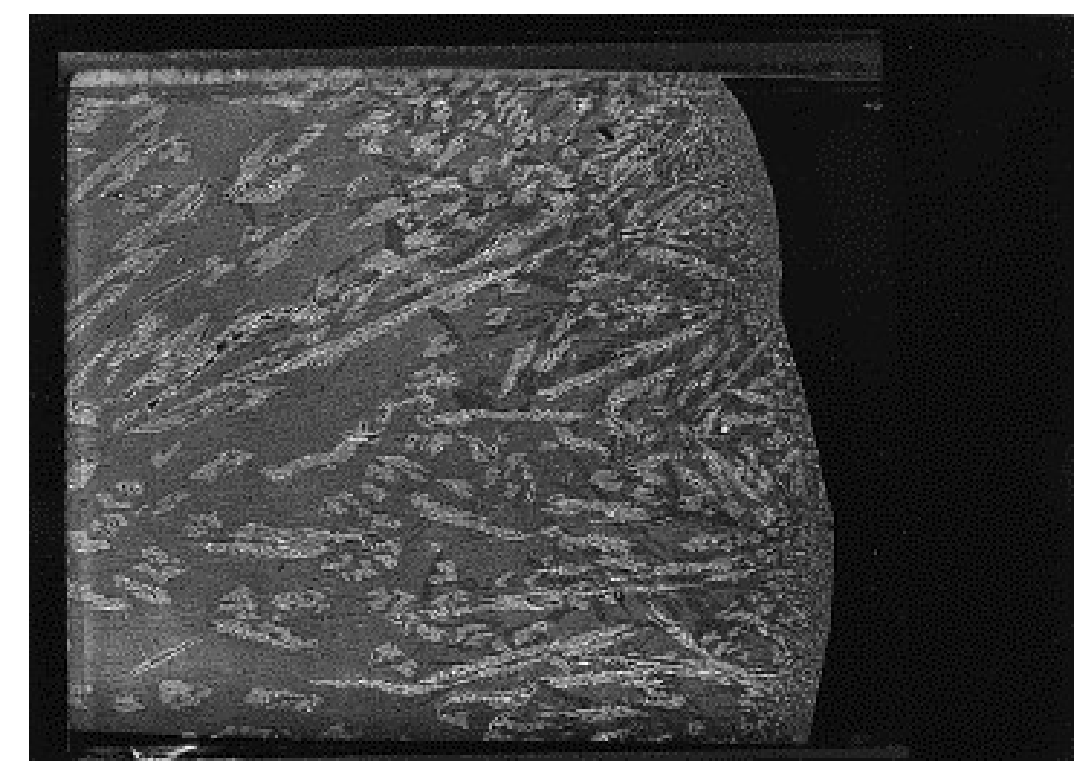

Fig. 3. SEM micrograph $(75 \times)$ of $4 \mathrm{M}$ glass-ceramic obtained at $1200^{\circ} \mathrm{C}$ for $2 \mathrm{~h}$. 
The crystallization degree is a function not only of the composition but also of the thermal treatment. In the XRD patterns of the $4 \mathrm{~T}$ sample (Fig. 4), the gradual flattening of the background and the corresponding peaks intensity increase starting from $15 \mathrm{~min}$ to $4 \mathrm{~h}$ represent the experimental evidence of the crystallinity increase. A total crystallization is reached after 1 h. The different tendency towards nucleation and crystallization, evaluated by the corresponding time-temperature-transformation (TTT) diagrams of Fig. 5, confirmed the above mentioned results: from the position of the curves separating the amorphous and the semicrystalline state it is possible to see that in the $1 \mathrm{RE}$ composition the crystallization kinetic is slow, while the $\mathrm{CaO}$ and $\mathrm{MgO}$ contribution, especially as dolomite addition in the $4 \mathrm{RC}$ original mixture, is fundamental for a fast crystallization mechanism.

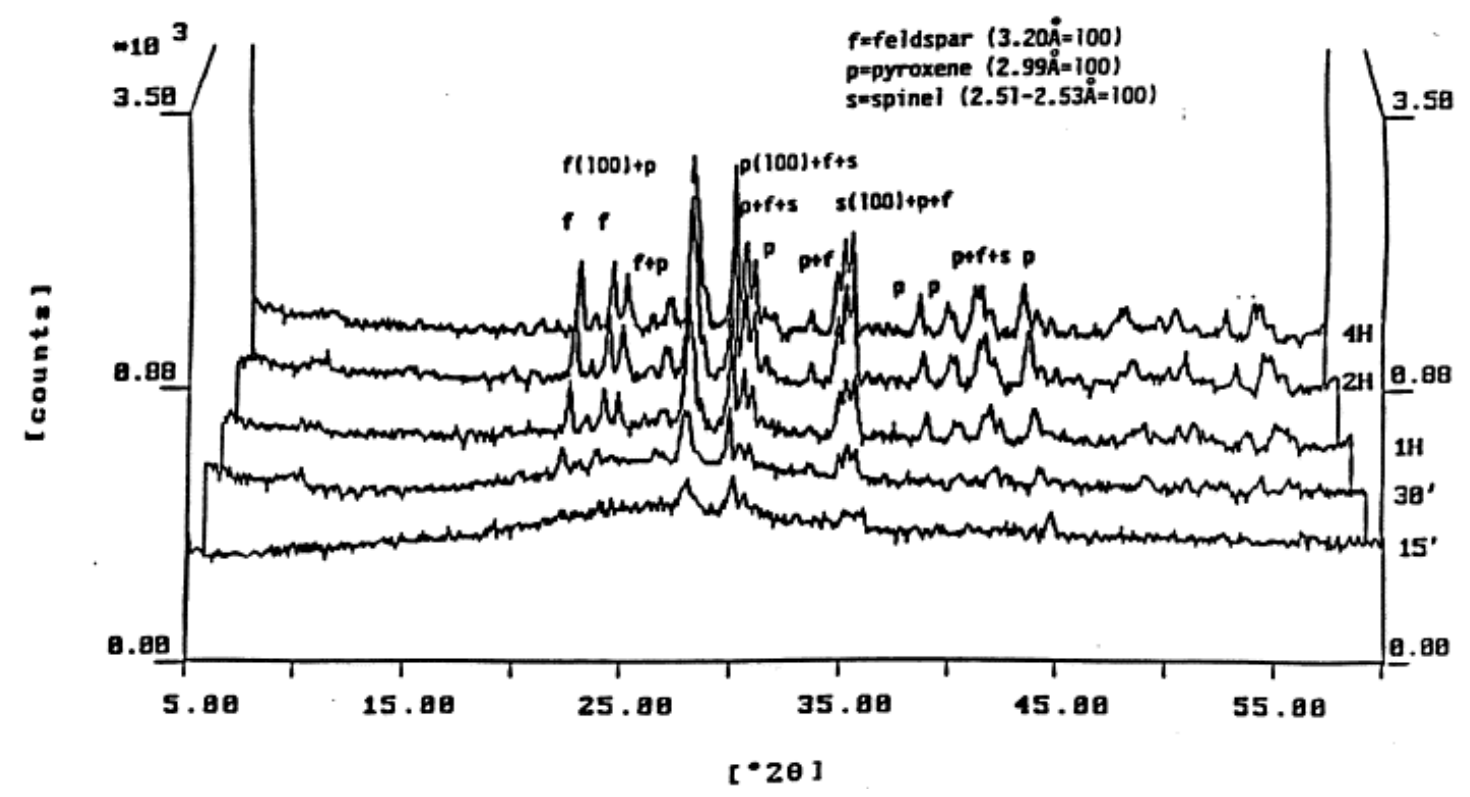

Fig. 4. XRD patterns from $4 \mathrm{~T}$ glass-ceramics obtained at $1100^{\circ} \mathrm{C}$ as function of the time.
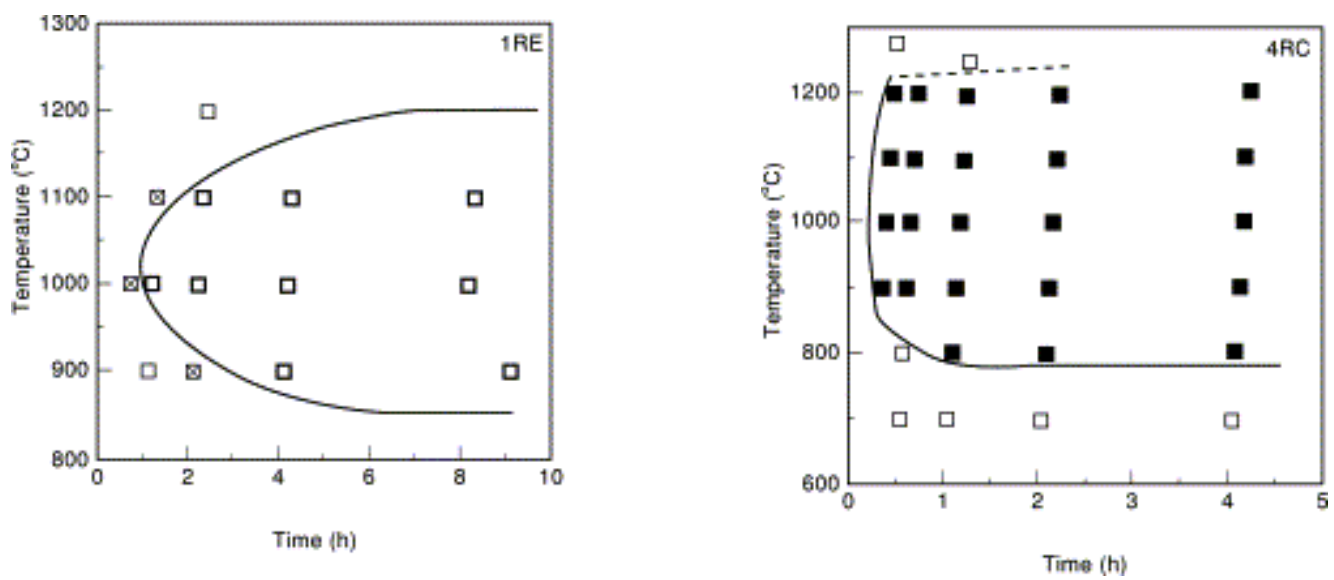

Fig. 5. TTT curves from 1RE and 4RC composition ( $\square$ : glass; $\bigotimes$ : starting crystallization; $\square$ : partial crystallization; $\mathbf{m}$ : total crystallization). 
Mechanical properties of the original glasses and the corresponding devitrified products display better values than the conventional glasses and/or the commercial glass-ceramics. After thermal treatments, it is possible to obtain crystallized products with improved mechanical properties, as is shown in Table 3. The 4T glass treated at the highest temperature shows a good combination of $H_{\mathrm{V}}, E$ and $K_{\mathrm{IC}}$ values.

Table 3. Mechanical properties of the original glasses and the corresponding glass-ceramics

\begin{tabular}{|c|c|c|c|c|c|}
\hline Composition & $\begin{array}{l}\text { Thermal treatment } \\
\left({ }^{\circ} \mathrm{C} / \mathrm{min}\right)\end{array}$ & Physical state & $H_{\mathrm{v}}(\mathrm{GPa})$ & $E(\mathrm{GPa})$ & $\begin{array}{c}K_{\mathrm{IC}} \\
\left(\mathrm{MPam}^{1 / 2}\right) \\
\end{array}$ \\
\hline $1 \mathrm{~T}$ & - & original glass & 5.5 & 48 & 1.1 \\
\hline $2 \mathrm{~T}$ & - & original glass & 5.6 & 42 & 0.8 \\
\hline \multirow[t]{6}{*}{$4 \mathrm{~T}$} & - & original glass & 6.4 & 74 & 1 \\
\hline & $1000 / 120$ & glass & 6.3 & 54 & 1 \\
\hline & $1000 / 120$ & crystal & 7.5 & 70 & 1.8 \\
\hline & $1100 / 120$ & glass & 6.3 & 81 & 1.3 \\
\hline & $1100 / 120$ & crystal & 7.3 & 91 & 2.8 \\
\hline & $1200 / 120$ & glass-ceramic & 7.3 & 92 & 3 \\
\hline \multirow[t]{2}{*}{$4 \mathrm{M}$} & $1100 / 120$ & glass-ceramic & 6.6 & 85 & 2 \\
\hline & $1200 / 120$ & glass-ceramic & 6.3 & 70 & 1.7 \\
\hline \multirow[t]{4}{*}{$1 \mathrm{RE}$} & - & original glass & 5.6 & 67 & 1 \\
\hline & $1000 / 120$ & glass-ceramic & 5.6 & 81 & 2.2 \\
\hline & $1000 / 480$ & glass-ceramic & 6.1 & 61 & 1.8 \\
\hline & $1100 / 120$ & glass-ceramic & 5.8 & 62 & 1.7 \\
\hline \multirow[t]{4}{*}{$2 \mathrm{RE}$} & - & original glass & 5.5 & 42 & 0.7 \\
\hline & $1000 / 120$ & glass-ceramic & 5.7 & 67 & 1.5 \\
\hline & $1000 / 480$ & glass-ceramic & 5.3 & 61 & 1.5 \\
\hline & $1100 / 120$ & glass-ceramic & 5.6 & 64 & 1.5 \\
\hline \multirow[t]{3}{*}{$3 R E$} & - & original glass & 5.5 & 49 & 0.7 \\
\hline & $900 / 240$ & glass-ceramic & 6.2 & 67 & 1.7 \\
\hline & $1000 / 120$ & glass-ceramic & 6.5 & 80 & 2 \\
\hline \multirow[t]{3}{*}{$4 \mathrm{RE}$} & - & original glass & 5.9 & 75 & 1 \\
\hline & $900 / 60$ & glass-ceramic & 5.7 & 46 & 1.1 \\
\hline & $1100 / 30$ & glass-ceramic & 5.7 & 65 & 1.2 \\
\hline $5 \mathrm{RE}$ & - & original glass & 6.2 & 58 & 0.9 \\
\hline \multirow[t]{2}{*}{$4 \mathrm{RC}$} & $1100 / 120$ & glass-ceramic & 5.5 & 93 & 2 \\
\hline & $1200 / 120$ & glass-ceramic & 4.6 & 106 & 2.1 \\
\hline
\end{tabular}


Lastly, the water durability test has shown that no visible etching existed at the surface of the original glasses. Conversely, in $\mathrm{HNO}_{3} 0.1 \mathrm{M}$ an appreciable etching as leaching of $\mathrm{Si}, \mathrm{Al}, \mathrm{Ca}$, $\mathrm{Mg}, \mathrm{Na}$ and $\mathrm{Fe}$ elements was noted only for the ternary formulations and especially corresponding to the Italian fly ash addition (4RC composition) due to its lower ratio of glass former and modifiers elements (Table 4).

Table 4. Mass loss $(\mathrm{g} / \mathrm{m} 2)$ of the only glasses that showed etching in $\mathrm{HNO}_{3} 0.1 \mathrm{M}$ for different times

\begin{tabular}{lrr}
\hline Composition & $\begin{array}{c}\text { Weight loss } \\
\left(\mathrm{g} / \mathrm{m}^{2}\right)\end{array}$ & $\begin{array}{r}\text { Weight loss } \\
\left(\mathrm{g} / \mathrm{m}^{2}\right)\end{array}$ \\
\hline $4 \mathrm{~T}$ & 113 & 192.85 \\
$4 \mathrm{M}$ & 134.92 & 212.3 \\
$4 \mathrm{RC}$ & 570.58 & 579.45 \\
\hline
\end{tabular}

\section{Conclusions}

In this work we demonstrated that it is possible to dispose coal fly ash through its valorization as a fundamental $(40-50 \mathrm{wt} \%)$ and alternative raw material to produce new coloured glass and glass-ceramic products with improved properties. To obtain amorphous materials mixing low percentage of fly ash with glass cullet ensures a suitable material workability; otherwise, to transform the glass into a glass-ceramic it is necessary to employ higher amounts of coal ash and help the crystallization process with alkaline-earth materials and transition elements (in this study we used waste dolomite). Before approaching the study of a material by the vitrification/devitrification technique, particular attention must be paid to the chemical nature of the coal fly ash. Suitable glass and glass-ceramic products can be obtained only if a good ratio between glassy network former and modifier elements exists, as here demonstrated by the best behaviour of the Spanish fly ash with respect to the Italian one.

\section{Acknowledgements}

The authors thank MURST and the CSIC-CNR Cooperation Programme for financial support. Thanks are also due to the Italian (Rete 2 of Reggio Emilia) and Spanish (Meirama and Teruel) Electric Power Plants and the La Vetri Company of Villa Poma, Mantova (Italy) for supplying coal fly ash and glass cullet. 


\section{References}

[1] Jablonski GL, Tyron SS. Overwiev of coal combustion by-product utilisation. In: Proceedings of the 5th International Pittsburgh Coal Conference, Pittsburgh, PA: University of Pittsburgh, 1988:15.

[2] DeGuire EJ, Risbud SH. J Mat Sci 1984;19:1760.

[3] Cumpston B, Shadman F, Risbud S. J Mat Sci 1992;27:1781.

[4] Cioffi R, Pernice P, Aronne A, Catauro M, Quattroni G. J Europ Ceram Soc 1994;13:143.

[5] Boccaccini AR, Bucker M, Bossert J. Tile and Bricks 1996;12(6):515.

[6] Queralt I, Querol X, Lo`pez-Soler A, Plana F. Fuel 1997;76:787.

[7] Barbieri L, Manfredini T, Queralt I, Rincon JMa, Romero M. Glass Tech 1997;38(5):165.

[8] Garc1'a Verduch A. Jornadas cientı'ficas sobre cerámica y vidrio. Sección de Ciencias Basíca de la Soc Esp Ceram Vidr y Universidad de Oviedo, 1980.

[9] Evans AG, Wilsnaw TR. Acta Metall 1976;24:939.

[10] Rincon JM, Capel F. Ceramics International 1985;11:97.

[11] Mendel JE. US DOE Report DOE/TIC-11400. Richland, WA: Materials Characterization Center, Pacific Northwest Laboratories, 1981.

[12] Strachan DM, Barnes BO, Turcotte RP. In: Moore JG, editor. Scientific basis for nuclear waste mana 